Original Article

\title{
POLYMERIC NANOPARTICLES CONTAINING TITHONIA DIVERSIFOLIA (HEMSL) A. GRAY FLOWERS ALCOHOLIC EXTRACT AND COATED BY HYALURONIC ACID: DEVELOPMENT, SYNTHESIS, AND CHARACTERIZATION
}

(Compliance with ethical standards: We submitted to the national genetic heritage management system and associated traditional knowledge and was registered in SisGen, in compliance with the provisions of Law 13,123/2015 and certificate number A516224).

\section{Authors: Fernanda Arriel Pedrozo Rezende1; Anna Luiza de Aveiro Ruocco'; Bruno Batista da Silva²; Robson Miranda da Gama3; José Armando-Jr ${ }^{3}$, Marcelo Guimarães ${ }^{4, A}$.}

${ }^{1}$ Graduation Student - Pharmacy Course - CCBS - Mackenzie Presbyterian University. São Paulo, SP, Brazil.

${ }^{2}$ Pharmacist - Semi-industrial Laboratory - Pharmacy Course - CCBS - Mackenzie Presbyterian University. São Paulo, SP, Brazil.

${ }^{3}$ Teacher - Laboratory of Teaching and Research of the Pharmacy Course, University Health Center, ABC (CUSABC), Santo André, SP, Brazil.

${ }^{4}$ Teacher - Semi-industrial Laboratory - Pharmacy Course - CCBS - Mackenzie Presbyterian University. São Paulo, Brazil. e-mail: marcelo.guimaraes@mackenzie.br.

\section{Article ID}

Keywords:

Polymeric nanoparticles;

Tithonia diversifolia

(Hemsl) A. Gray;

poly (n-butyl-cyanoacry-

late), hyaluronic acid.

\begin{abstract}
Nanoparticles are systems formed by biodegradable, synthetic or natural polymers, that have gained significant importance in different industry segments, as well as being the highlight of essential researches. These tiny particles present various promising characteristics, such as: site-specific and gradual drug release and improvement of active principle solubility and stability. The combination of nanotechnology with medicinal plants could be able to enhance the action of plant extracts, such so that many innovative drug carriers have emerged, including polymeric nanoparticles. The objective of this study was to synthesize and characterize polymeric nanoparticles coated with hyaluronic acid, containing Tithonia diversifolia (Hemsl) A. Gray flowers alcoholic extract, aiming to improve the nanoparticle's stability, for possible future applications. The synthesis occurred through emulsion polymerization, where the monomer n-butyl-cyanoacrylate was incorporated with Dextran into an aqueous $\mathrm{HCl}$ solution, with posterior addition of
\end{abstract}

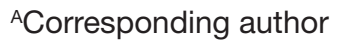

Marcelo Guimarães - E-mail: marcelo.guimaraes@mackenzie.br - ORCID: https://orcid.org/0000-0002-9480-2957
}

DOI: https://doi.org/10.31415/bjns.v3i1.88 - Article received on: February 26, 2020; accepted February 27, 2020; published on March 10, 2020. Brazilian Journal of Natural Sciences, Vol. 3, N.1, March 2020. Available online from March 10, 2020 , ISSN 2595-0584. www.bjns.com.br. All authors contributed equally to the article. The authors declare that there is no conflict of interest. This is an open access article under the CC - BY license: http://creativecommons.org/licenses/by/4.0. 


\section{Informações do artigo}

Palavras Chave:

Nanopartículas polimé-

ricas;

Tithonia diversifolia

(Hemsl) A. Gray;

poli (n-butil-cianoacrila-

to), ácido hialurônico. the alcoholic plant extract and neutralization reaction with $\mathrm{NaOH}$. Stability parameters, such as hydrodynamic diameter, polydispersity index, zeta potential, spectroscopy (IV), Scanning Electron Microscopy (SEM), thermogravimetry (TG) and Differential Exploration Calorimetry (DSC) were analysed. The nanoparticle system was evaluated taking into consideration particle stability prior and posterior to the addition of the extract, as well as coated and uncoated particles. The results demonstrated the good reactivity of the monomers of cyanoacrylates, as well as effectiveness of hyaluronic acid in relation to the proposed objective, evidenced in the results obtained by Infrared Spectroscopy, by SEM, DSC and, also, TG. The study demonstrated that there are possible future applications for this method.

\section{Resumo}

As nanopartículas são classificadas como qualquer material ou partícula coloidal, farmacologicamente ativo ou inerte, com a capacidade de veicular agentes terapêuticos, que se encontrem no intervalo nanométrico de $10 \mathrm{a}$ $1000 \mathrm{~nm}(1 \mu \mathrm{m})$. Têm sido utilizadas no setor farmacêutico para várias aplicações, obtendo um significativo avanço na liberação de fármacos em sítios específicos. Observa-se uma notável melhora na solubilidade e estabilidade dos princípios ativos incorporados, assim como da velocidade de distribuição. Esse estudo apresenta o processo de desenvolvimento de nanopartículas poliméricas revestidas com ácido hialurônico, contendo o extrato alcóolico de folhas de Tithonia diversifolia (Hemsl) A. Gray. O objetivo da pesquisa focou o oferecimento de subsídios nanotecnólogicos para aplicações futuras, viabilizando a melhoria da estabilidade do princípio ativo e possivelmente da sua ação terapêutica. A síntese das nanopartículas ocorreu através do processo de polimerização por emulsão, onde foram adicionados a uma solução aquosa de $\mathrm{HCl}$ 0,01M (pH 2,5), o monômero $n$-butil-cianoacrilato (BCA), juntamente com Dextran', com posterior incorporação do extrato vegetal e neutralização do meio. O nanossistema obtido foi avaliado por diferentes métodos físico-químicos que incluíram a avaliação da estabilidade física das nanopartículas pela Espectroscopia (IV), Microscopia Eletrônica de Varredura (MEV), Termogravimetria (TG) e Calorimetria Exploratória Diferencial (DSC). Os resultados das análises a que as amostras foram submetidas apresentam indicativos que sugerem sucesso na obtenção de um nanossistema de liberação de fármacos estável e inovador, bem como uma efetividade do ácido hialurônico em relação ao objetivo proposto, evidenciada nos resultados obtidos por Espectroscopia (IV), Microscopia Eletrônica de Varredura (MEV), Calorimetria Exploratória de Varredura (DSC), bem como pela Termogravimetria (TG).

\section{Introduction}

Over the last decade, there has been an intensification in researches involving vectors that can control drug release at specific sites of action, improving both the rate of distribuition and the dosage regime. The main systems studied for these purposes have been microparticles and coloidal systems (liposomes and 
nanoparticles). Nanoparticles are systems formed by biodegradable, synthetic or natural polymers, that have gained significant importance in different industry segments, as well as being the highlight of essential researches. These tiny particles are applicable in the health segment due to the easiness of controlling chemical structures, surface functionalities and particle diameter (AKAGI et al., 2007).

Nanostructures present various promising characteristics, such as: site-specific and gradual drug release, as well as improvement of active principle solubility and stability, enhancement of the desired action of a formulation, and allowing the combination of active substances of varying hydrophilic/lipofilic degrees (SINTOV \& SHAPIRO, 2004; CUNHA et al., 2003).

Several nanotechnological stratagies, such as polymeric nanoparticles, allow substances with different properties to be applied in the same formulation, making it possible to alter the properties and behaviour of a given substance in a biological environment (BONIFÁCIO et al., 2014; GUTERRES, et al., 2012).

Polymeric nanoparticles present diameters ranging from 10 to 1000 nanometers, and can be synthesized through various methods. The most common methods used for the production of polymeric nanoparticles are: in situ polymerization (with dispersed monomers) and precipitation method of preformed polymers. Regardless of the chosen method, the products are obtained as colloidal dispersions or aqueous microemulsions, generating thermodynamically stable systems (BEHAN, et al., 2001; BERTHOLON, et al., 2006).

Compared with conventional formulations, polymeric nanoparticles are capable of increasing the solubility of constituents, reducing the therapeutic dose and improving absorption of active componentes. Furthermore, when circulating in the bloodstream, nanoparticles have the advantages of being stable, non-toxic, non-thrombogenic, non-immunogenic and non-inflammatory (BONIFÁCIO et al., 2014, SIMEONOVA, 2009).

With the intention of enhancing the stability of the nanoparticles, the present study uses the alternative of hyaluronic acid coating, in an attempt of increasing the effectiveness of the nanosystem as a whole.

In parallel, the use of plants for medicinal purposes has aroused a growing interest in several sci- entific communities, as it allows the development of innovative products with lower potential side effects (COSTA et al., 2010). Plant extracts provide several beneficial properties with different applications, however they are not physical-chemically stable, which may lead to the loss of their antioxidant properties (DAUDT et al., 2013). Thus, the combination of nanotechnology with medicinal plants might be able to enhance the action of plant extracts, such so that many innovative drug carriers have emerged, including polymeric nanoparticles.

Several authors have studies based on active ingredients derived from plants that present antioxidante and healing properties. Contemplated within the Asteraceae family, the species Tithonia diversifolia (Hemsl) A. Gray has been used as a medicinal plant (LACERDA et al., 2011), having anti-inflammatory action (OWOYELE et al., 2004) and containing chemical compounds such as total phenols, tannins and flavonoids that also contribute to an antioxidant (GAMA et al., 2013), anticancer (CHOWDHURY et al., 2002; CAI et al., 2004), antimicrobial (NASCIMENTO et al., 2000; CUSHINE \& LAMB, 2005) and healing action (NAYAK \& PEREIRA, 2006).

\section{Objective}

The objective of this study was to develop, synthesize and characterize polymeric nanoparticles coated with hyaluronic acid, containing Tithonia diversifolia (Hemsl) A. Gray flowers alcoholic extract, aiming to improve the nanoparticle's stability, for possible future applications.

\section{Materials and methods}

\section{Alcoholic extract preparation}

The alcoholic extract is obtained using the flowers of the Tithonia diversifolia (Hemsl) A. Gray plant. The flowers undergo a week long drying process using a hot air chamber at approximately $50^{\circ} \mathrm{C}$. These flowers are then reduced by a mill, remaining in a $100 \%$ ethanol solution, under stirring and at room temperature for 24 hours. This mixture is then subjected to a filtration process and through the use of a rotary evaporator conected to a vacum pump, the extract is condensed to a concentration of $0.1 \mathrm{~g} / \mathrm{mL}$ (GAMA, R.M. et al., 2014). 


\section{$\mathrm{HCL}$ and $\mathrm{NaOH}$ solutions}

Hydrocloric acid solution $(\mathrm{HCl})$ and sodium hydroxide solution $(\mathrm{NaOH})$ were previously prepared. The ideal $\mathrm{HCl}$ solution should have a hydrogen potential $(\mathrm{pH})$ close to 2.5 , as the polymerization reaction is $\mathrm{pH}$ dependent, occurring best in an acidic medium. The $\mathrm{NaOH}$ solution is basic, being able to neutralize the acidic $\mathrm{pH}$ of the reaction medium and thus interrupt the polymerization reaction (SCHAFFAZIK et al., 2003; VAUTHIER et al., 2003).

\section{Polymerization}

The nanoparticles were synthesized through the process of emulsion polymerization, at $800 \mathrm{rpm}$, where the monomer n-butyl-cyanoacrylate together with $100 \mathrm{mg}$ of Dextran ${ }^{\otimes}$ were incorporated into 10 $\mathrm{mL}$ of the aqueous $\mathrm{HCl}$ solution $(0,01 \mathrm{M}, \mathrm{pH} 2,5)$, with posterior addition of the alcoholic plant extract and final reaction neutralization with $\mathrm{NaOH}(\mathrm{pH}$ 7,0 \pm 0,3 ). The resulting polymer poly (n-butyl-cyanoacrylate) (PBCA) was then filtered and stored in an Eppendorf, being labeled as 'Plain'PBCA.

For the incorporation of the extract, the same process was repeated, but after one hour of the continuous stirring, $1 \mathrm{~mL}$ of PBCA was removed and $1 \mathrm{~mL}$ of the alcoholic plant extract was added to the mixture present in the conical flask. The stirring carried on for three hours and then process was then terminated with the addition of the $\mathrm{NaOH}$ solution and posterior filtration with a glass funnel and filter paper. The resulting mixture was stored and identified as PBCA-Extract (polymer containing the alcoholic plant extract) (GUIMARÃES, M., 2015).

\section{Hyaluronic acid coating}

The process of coating was based on the work of HE and collaborators (2009), where a 1\% (w/v) hyaluronic acid dispersion is prepared using purified water, under stirring. The obtained dispersion was posteriorly added, drop by drop, under stirring ( $800 \mathrm{rpm})$ to 5 $\mathrm{mL}$ of the PBCA-Extract (GUIMARÃES, 2015). After one hour, a sample was collected and labeled as Coated PBCA containing Extract. The same method was applied to $5 \mathrm{~mL}$ of the 'Plain'PBCA and the resulting mixture obtained was labeled as Coated PBCA. The final stored samples were posteriorly lyophilized in order to carry out the absorption spectroscopy in the infrared region and the scanning electron microscopy.

\section{Nanoparticle characterization \\ pH and macroscopic characterization}

$\mathrm{pH}$ readings were carried out in triplicates for each reading and the mean value for each measurement was calculated. Macroscopic characterization was based on the visual color of the obtained samples, as well as possible presence of precipitates or phase separation posterior to the end of the polymerization reaction.

\section{Medium hydrodynamic diameter, nanoparticle size distribution and zeta potential}

The polydispersivity index, hydrodynamic diameter and the particle size distribution were performed with the aid of a Zetasizer equipment (3000 HS (Malvern Instruments), at $25^{\circ} \mathrm{C}$ and $90^{\circ}$, through the process of light scattering. Zeta potential readings were based on the electrophoretic mobility, utilizing a force field of $20 \mathrm{~V} / \mathrm{cm}$.

The analyses were performed in triplicate, aiming to reduce the possible errors associated with the technique.

\section{Infrared absorption spectroscopy (FTIR)}

Spectroscopy provides information on the concentration of specific compounds and their chemical and morphological structure. Vibrational spectroscopies, more specifically infrared spectroscopy, allow the identification of functional groups corresponding to the absorption bands generated by the vibration of the molecule/atom. The infrared band most commonly used is the medium infrared $\left(400-4000 \mathrm{~cm}^{-1}\right)$, due to the easiness of associating a band with a specific functional group (CUFFINI, 2009).

For the proposed study, pellets were obtained through sample mixture with potassium bromide $(\mathrm{KBr})$. Spectrums were performed utilizing a Fourier Transform Infrared spectrometer (FT-IR).

\section{Characterization of nanoparticles by scanning} electron microscopy (SEM) 
SEM has been widely used to evaluate the structures of nanoparticles, including their shape and size, and depending on their formulation, average particle size variation, as well as general effects of the drug in the reactional medium (SCHAFFAZICK et al., 2003). Samples were analyzed with a JEOL microscope, model JSM, 6510LV series and a magnification of 30x 5000x.

\section{Differential scanning calorimetry (DSC)}

Samples of 'Plain'PBCA, PBCA-extract, Coated PBCA coated and Coated PBCA containing Extract were analyzed. The analyses were performed in a DSC 7020 scanning calorimeter (Exstar, SII Nano Technology Inc., Japan), $25-400{ }^{\circ} \mathrm{C}$, utilizing approximately $2 \mathrm{mg}$ of each sample, heating ratio of $10^{\circ} \mathrm{C} / \mathrm{min}$ and dynamic atmosphere of nitrogen with flow rate of 50 $\mathrm{ml} / \mathrm{min}$.

\section{Thermogravimetry (TG)}

Thermogravimetry is contemplated within the thermal analysis methods and aims to verify the weight variation of a certain substance(s), in relation to the temperature and/or time variation, under controlled conditions of temperature and atmosphere (VOGEL, 2017).

The resulting graphs can be used to obtain information regarding the thermal stability of the substance, its composition and intermediate products/ residues formed (SILVA et al., 2007). TG analysis was carried out in a Netzsch cell (STA 449F3a) with nitrogen atmosphere. Samples of 'Plain' PBCA, PBCA-extract, Coated PBCA and Coated PBCA containing extract were analyzed

\section{Results and discussion}

Regarding macroscopic aspects, the nanoparticle emulsion presented itself as homogeneous, with a whitish color and milky aspect, without the presence of precipitate or phase separation (Figure 1). The emulsion remained with its whitish tint even after the addition of the yellow alcoholic plant extract. The aspect of the formulation remained constant throughout the experiment. The non-evidence of phase separation suggests that the combination of extract and polymer obtained a good stability.

\section{Figure 1.}
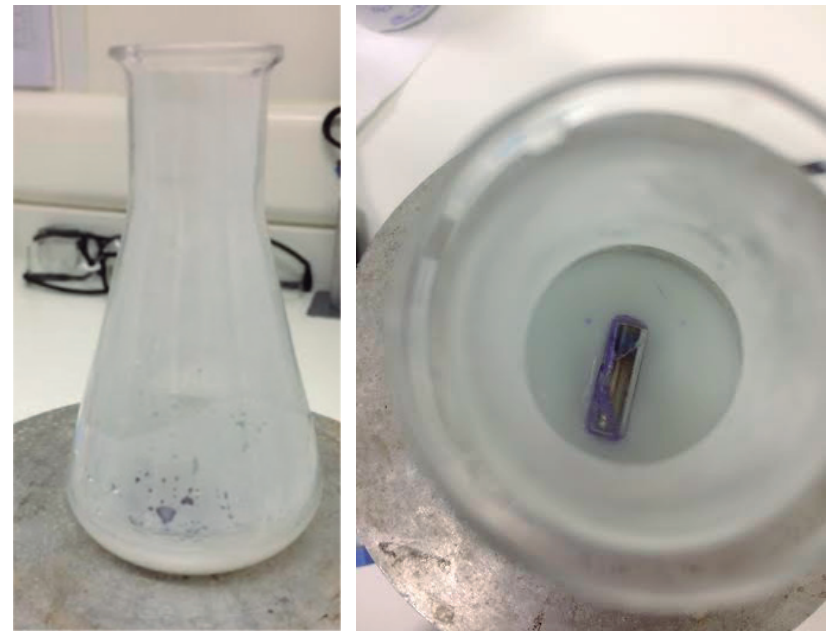

Figure 1 - Appearance of the nanoparticle emulsion before the addition of the alcoholic plant extract

In terms of the $\mathrm{pH}$ variation (Figure 2), it is possible to see that both 'Plain'PBCA and PBCA-Extract formulations started with a $\mathrm{pH} 7.0 \pm 0.3$, since this is the $\mathrm{pH}$ required for the completion of the polymerization reaction. $\mathrm{pH}$ value remained relatively stable throughout the weeks, within the variation of \pm 0.3 .

\section{Figure 2.}

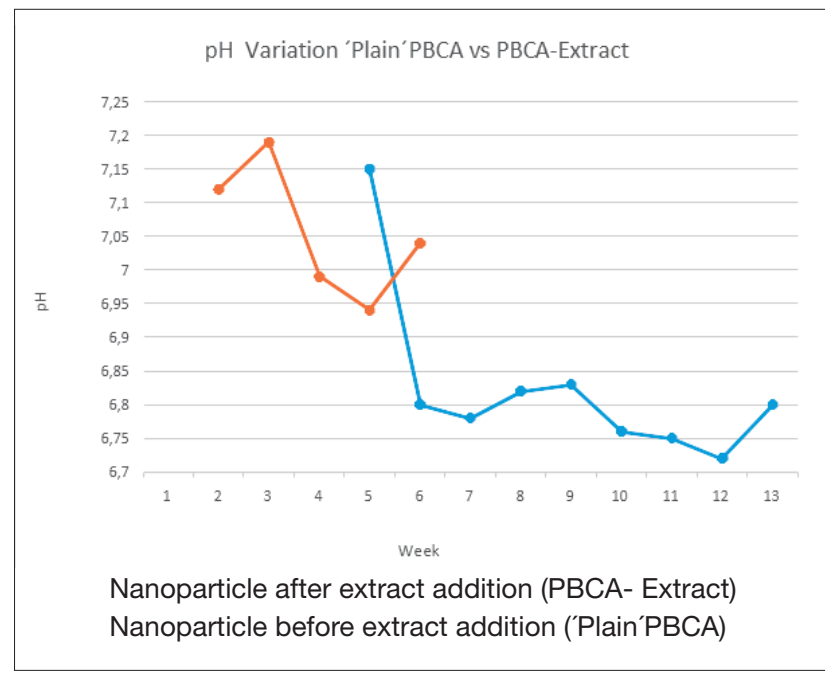

Figure 2 - Weekly $\mathrm{pH}$ comparison of the emulsion with and without the alcoholic plant extract

The fact that the $\mathrm{pH}$ remained close to neutrality is a good indicator of formulation stability, as an increase in acidity could indicate possible polymer degradation, due to the hydrolysis of the polymeric chain, generating carboxyl groups (SANTOS, 2010). 
The nanoparticles presented a mean diameter (151.6 nm for the 'Plain'PBCA and $180.0 \mathrm{~nm}$ for the PBCA-Extract), consistent with the range described in literature of $100-300 \mathrm{~nm}$ (Table 1). The values obtained for PBCA without the extract are similar to those described by Bertholon et al. (2006) also using the emulsion polymerization method with Dextran ${ }^{\circledR}$. An increase in the mean diameter, as well as in the polydispersivity index was observed, which could be explained by the addition of the extract before the end of the polymerization reaction, since it may lead to the formation of larger particles (SCHAFFAZICK, 2003). This average hydrodynamic increase can be indicative of the adsorption of the extract to the Polymer, according to Table 1.

Table 1 - Determination of the mean hydrodynamic diameter, polydispersity index and zeta potential of the nanoparticles

\begin{tabular}{|c|c|c|c|}
\hline Nanoparticle & $\begin{array}{c}\text { Mean hydrodynamic } \\
\text { diameter }(\mathbf{n m})\end{array}$ & $\begin{array}{c}\text { Polydispersity } \\
\text { Index }\end{array}$ & Zeta potential (mV) \\
\hline 'Plain'PBCA & $151,6 \pm 5,4$ & $0,06 \pm 0,02$ & $-1,46 \pm 1,04$ \\
\hline PBCA-Extract & $180,0 \pm 2,2$ & $0,10 \pm 0,33$ & $-0,70 \pm 1,27$ \\
\hline
\end{tabular}

*Values expressed as mean \pm standard deviation $(n=3)$

The zeta potential is associated with the surface potential of particles. Results obtained showed slightly negative values, which may be associated with the fact that the reaction occurs in an acidic medium (lower $\mathrm{pH})$, contributing to a reduced dissociation of the free acrylic acid groups (REDDY \& MURTHY, 2004).

The polydispersivity index is associated with the distribution of the particle weight, being contemplated on a scale from 0 to 1 . Both results obtained for the samples ( 0.06 for the 'Plain'PBCA and 0.10 for the PBCA-Extract) demonstrated a good distribution, given that values below 0.2 present a narrow distribution of size, that is, a system closer to being monodispersed (DAS et al., 2012). The standard deviation was low, suggesting that the method showed good reproducibility.

According to Figure 3, a relatively similar behavior can be perceived between the three samples, with only a small variation in transmittance. The sample presented by a red line on the graph referes to the nanoparticle containing the plant extract but without the hyaluronic acid coating. One can observe that the sample presented significant peaks, demonstrating a greater instability when compared to the other curves. This result suggests that the hyaluronic acid coating of the nanoparticle containing the extract is essential in the process of stabilizing them.

\section{Figure 3.}

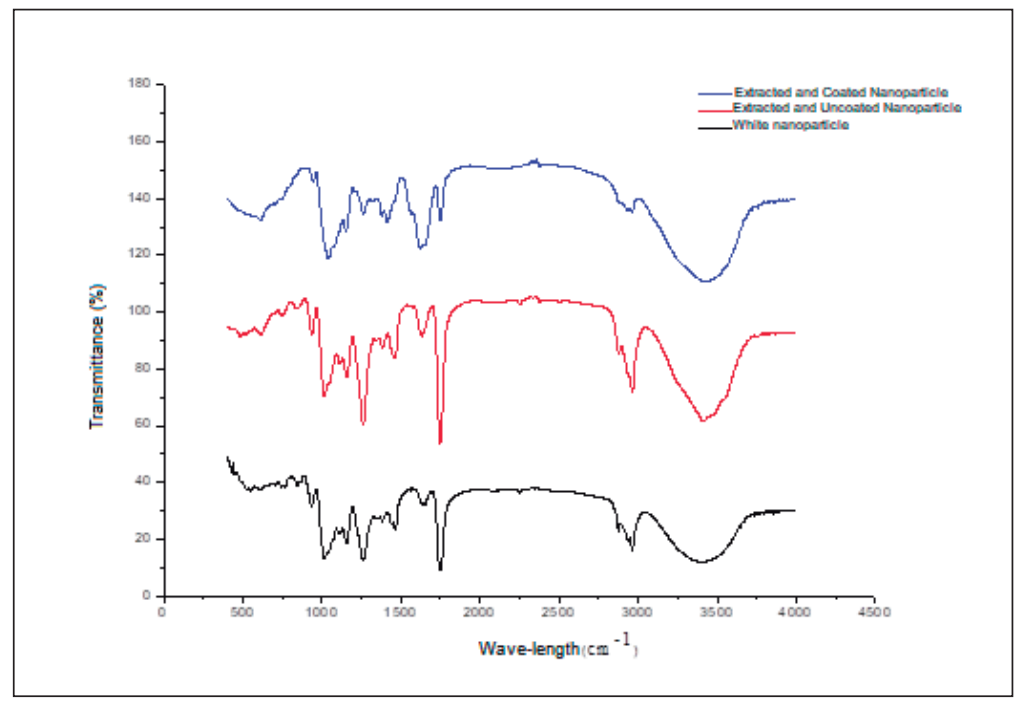

Figure 3 - Infrared spectroscopy of the obtained samples 
The characterization of nanoparticles by scanning electron microscopy (SEM), was also obtained (see Fig res 4,5 , and 6 ).

\section{Figure 4.}

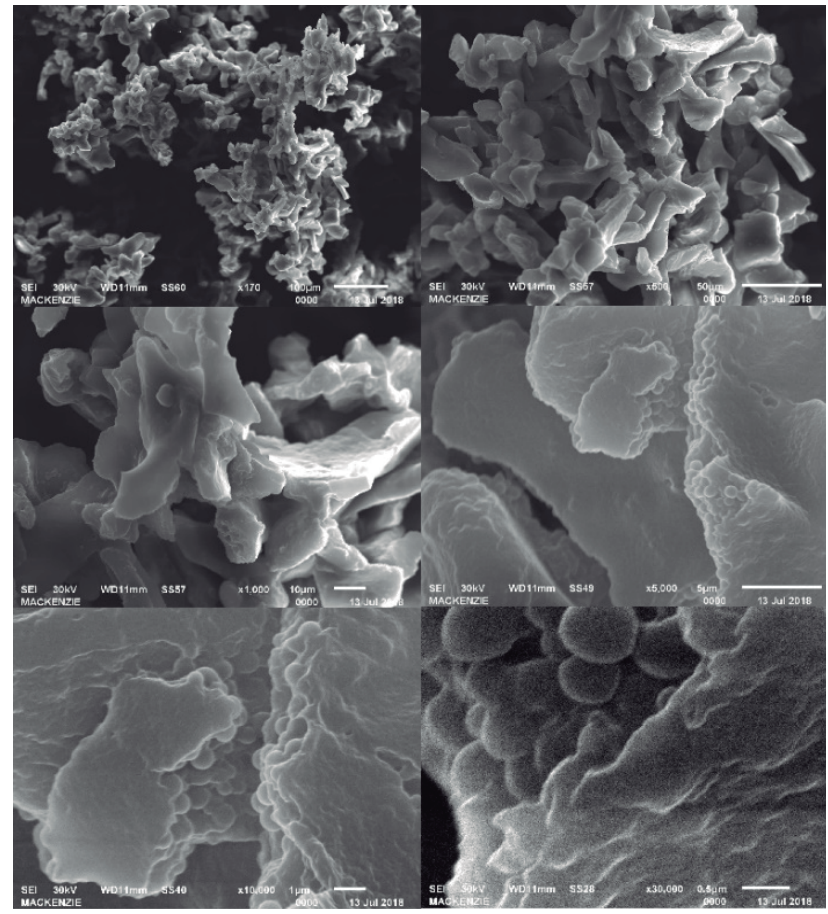

Figure 4 - 'Plain' PBCA SEM scan.

Figure 5.

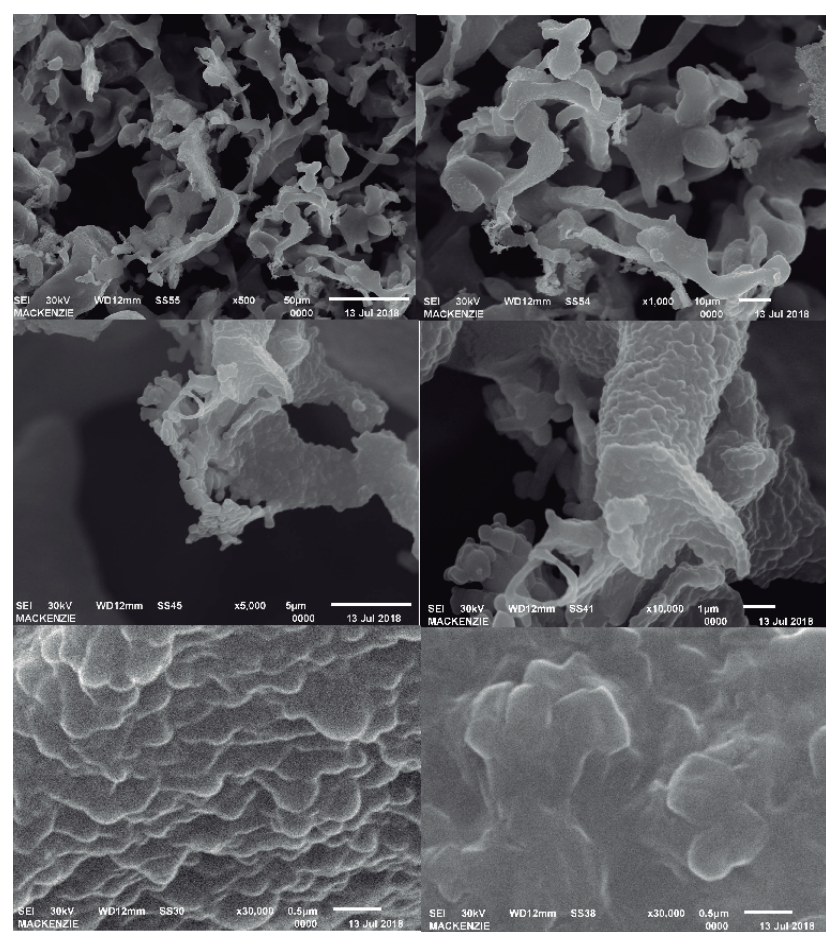

Figure 5 - PBCA-Extract without coating SEM scan

\section{Figure 6.}

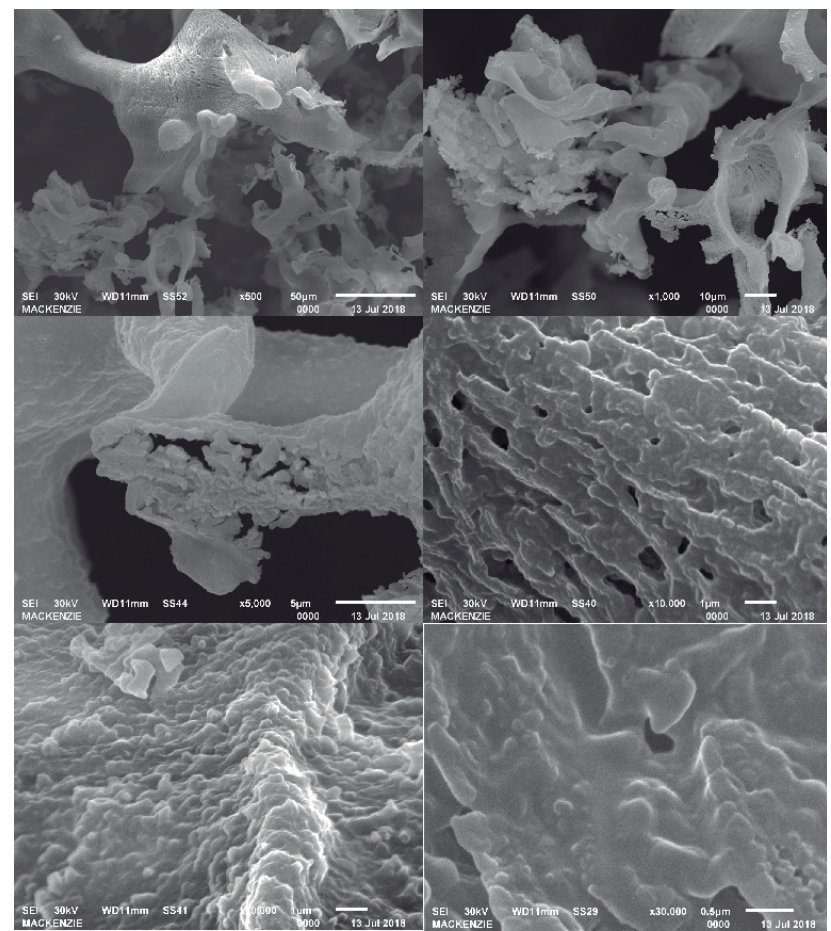

Figure 6 - Coated PBCA with plant extract SEM scan

The images provided by SEM demonstrated that the nanoparticles were not completely spherical, but rather varied in format (Figures 4, 5, and 6). Although no particle size alteration was observed posterior to the addition of the plant extract, a change in the particle agglomeration state could be noticed. Particles were perceived as being more dispersed, possibly due to the presence of the plant extract inside the nanoparticle (Figure 5).

Coated nanoparticles presented different superficial characteristics (Figure 6) when compared to the other two samples. Particles appeared to have a spongy characteristic to them due to clearly visible superficial pores.

The thermal stability of nanoparticles was evaluated through differential scanning calorimetry (DSC) and thermogravimetry (TG) (Figure 7).

The curve of the DSC analysis (Figure 7) obtained for the nanoparticle containing the plant extract and the coating presents an endothermic peak in the range of $300-450^{\circ} \mathrm{C}$, which is characteristic of simultaneous and/or subsequent events. One can infer that this event occurred due to loss of moisture during the analysis. The beginning of the process of degradation of the polymeric structure referring to the sample with 
extract and with coating is approximately at $200^{\circ} \mathrm{C}$.

TG analysis of the main formulation developed in this study (nanoparticles containing plant extract and with coating) demonstrated the absence of an exo- thermic peak (Figure 8). This result may be indicative of possible adsorption of the hyaluronic coating to the surface of the nanoparticles, protecting the latter against degradation.

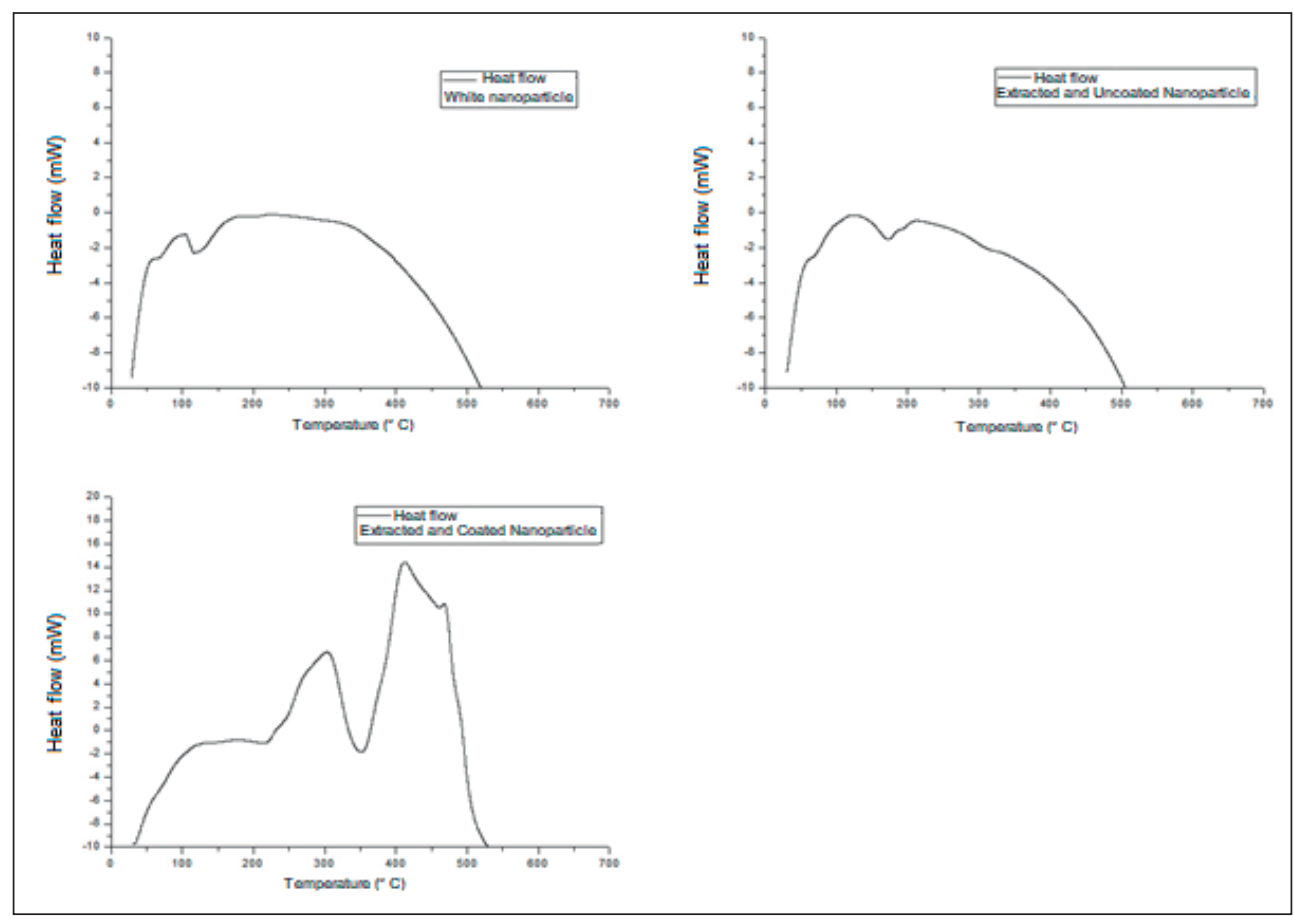

Figure 7 - DSC analysis of 'Plain' PBCA, PBCA-Extract without coating and Coated PBCA containing extract, obtained using sealed aluminum capsule, heating ratio $10^{\circ} \mathrm{C} /$ in and nitrogen atmosphere with a flow rate of $50 \mathrm{~mL} /$ minute.

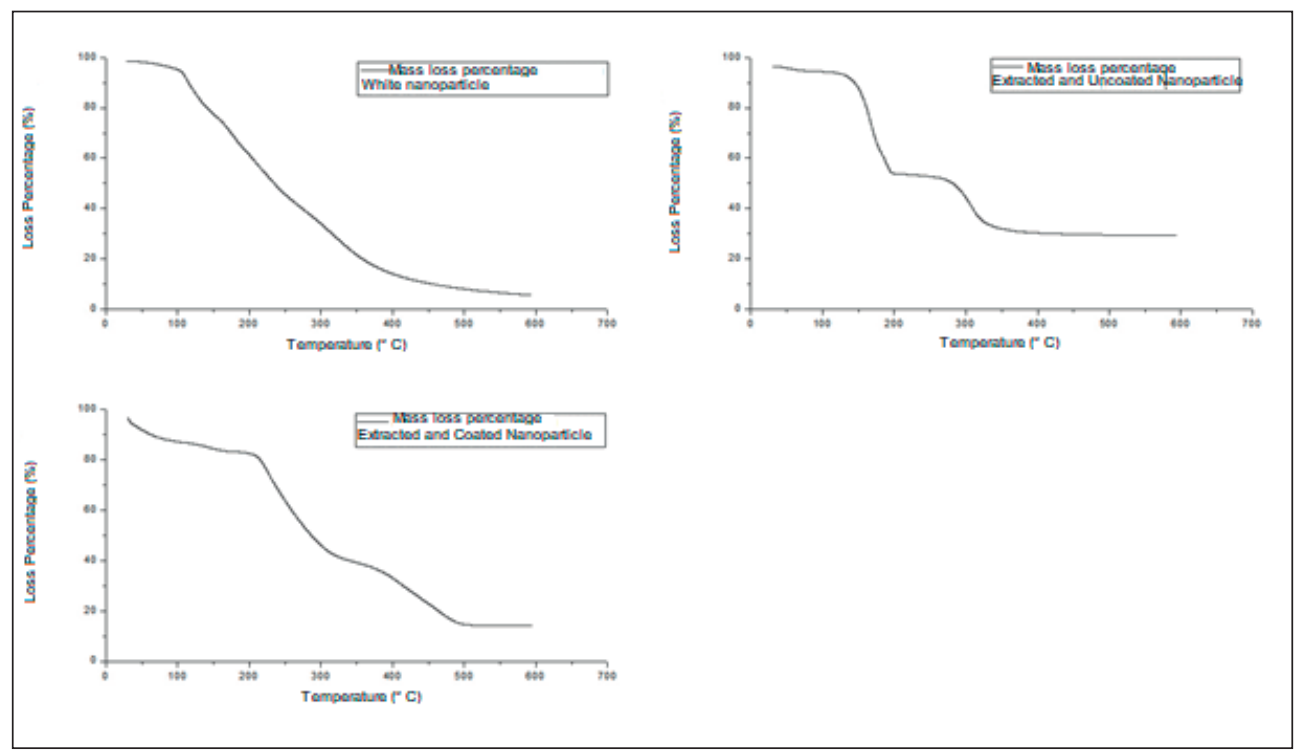

Figure 8 - Curves refering to TG analysis of 'Plain' PBCA nanoparticles, PBCA-Extract without coating and Coated PBCA containing extract, obtained using sealed aluminum capsule, heating ratio of $10^{\circ} \mathrm{C} / \mathrm{min}$ and dynamic nitrogen atmosphere with a flow rate of $100 \mathrm{~mL} /$ minute. 
Furthermore, the endothermic events of the nanoparticles containing plant extract and coating appear wider and/or displaced, indicating possible interactions between particle, extract and the hyaluronic acid coating. This observation also reinforces evidence of nanoparticle coating.

\section{Conclusion}

Considering the objectives of this work, one can conclude that the development of the nanoparticles of poly (n-butyl-cyanoacrylate) allowed the addition of the alcoholic extract of the plant Tithonia diversifolia (HEMSL) A. Gray, as well as the use of hyaluronic acid as a coating medium. This process generated a nanostructure, which remained stable in relation to its physical, and morphological characteristics. Results evidenced by spectroscopy, SEM, DSC and also by TG, demonstrate the effectiveness of hyaluronic acid as a coating medium, supporting the qualitative aspect of the reasearch to improve the physicochemical stability of the nanosystem. Future studies taking into consideration these analyses may add to the set of nanotechnological subsidies for the pharmaceutical área.

\section{References}

AKAGI T; BABA M; AKASHI M. Polymer 2007, 48, 6729. [CrossRef]. www.crossref.org > Acesso em $8 / 05 / 2015$.

BEHAN, N.; BIRKINSHAW, C.; CLARKE, N. Poly n-butyl cyanoacrylate nanoparticles: a mechanism study of polymerization and particle formation. Biomaterials, v.22, p. 1335-1344, 2001.

BERTHOLON, I.; VAUTHIER, C.; LABARRE, D. Complement activation by core-shell poly(isobutylcyanoacrylate)-polysaccharide nanoparticles: Influences of surface morphology, length, and type of polysaccharide. Pharmaceutical Research, v. 23, p.1313-1323, 2006.

BONIFÁCIO B V; et al. Nanotechnology-based drug delivery systems and herbal medicines: a review. Int J Nanomedicine. 2014; 9: 1-15. Disponível em: <https://www.ncbi.nlm.nih.gov/pmc/articles/ PMC3862741/> Acesso em: 17 de jul. 2018.

CAI Y.; et al. Antioxidant activity and phenolic compounds of 112 traditional Chinese medicinal plants associated with anticancer. Life Science. v. 74, n.11, pp. 2157-2184, 2004.
CHOWDHURY A R.; et al. Luteolin, an emerging anti-cancer flavonoid, poisons eukaryotic DNA topoisomerase I. Biochemistry Journal. v. 366, n. 5, pp. 653-661, 2002.

COSTA EMMB, BARBOSA A S, ARRUDA T A, et al. Estudo in vitro da ação antimicrobiana de extratos de plantas contra Enterococcus faecalis. J Bras Patol Med Lab. 2010; 46(3):175-180.

CUFFINI Silvia L; PITALUGA JUNIOR Altivo; TOMBARI Dora. Polimorfismo em Fármacos. In: STORPIRTIS, Sílvia et al. Biofarmcotécnica. Rio de Janeiro: Guanabara Koogan, 2009. p. 26-28.

CUNHA ASC, JR, et al. Microemulsões como veículo de drogas para administração ocular tópica. Arq Bras Oftamol. 2003;66(3):385-391.

CUSHINE T P T.; LAMB A J. Antimicrobial activity of flavonoids. International Journal Antimicrobials Agents. v. 26, n. 5, pp. 343,356, 2005.

DAUDT R M. et al. A nanotecnologia como estratégia para o desenvolvimento de cosméticos. Cienc. Cult., São Paulo, vol.65, n.3, Julho 2013. Disponível em: http://cienciaecultura.bvs.br/scielo.php?scrip$\mathrm{t}=$ sci_arttext\&pid=S0009- 67252013000300011\&ln$\mathrm{g}=\mathrm{en} \& \mathrm{nrm}=\mathrm{iso}>$ Acesso em: 4 Outubro 2017.

DAS S; NG W K.; TAN R B H. Are nanostructured lipid carriers (NLCs) better than solid lipid nanoparticles (SLNs): development, characterizations and comparative evaluations of clotrimazole-loaded SLNs and NLCs? European journal of pharmaceutical sciences : official journal of the European Federation for Pharmaceutical Sciences, v. 47, n. 1, p. 139-51, 2012.

GAMA R M; ARMANDO-JR J, GUIMARÃES M. Phytochemical screening and antioxidant activity of etanol extract of Tithonia diversifolia (Hemsl) A. Gray dry flowers. Asian Pac J Trop Biomed 2014; 4(9): 740742 .

GUIMARÃES M. Desenvolvimento de nanopartículas de poli (n-butil-cianoacrilato) com zidovudina revestidas por ácido hialurônico para veiculação em gel de uso transdérmico. 2015. 149 p. Tese (Doutorado) - Curso de Farmácia, Produção e Controle Farmacêuticos, Universidade de São Paulo, São Paulo, 2015.

GUTERRES, S.S.; BNVENUTTI, E.V.; POHLMANN, A.R.Nanopartículas poliméricas para administração de fármacos. In: DURÁN, N.; MATTOSO, L.H.C.; MORAIS, C.P. (eds), Nanotecnologia: Introdução, preparação e caracterização de nanomateriais e exemplos de aplicação. 2 ed. Artliber Editora. São Paulo, 2012. 
HE, M.; ZHAO, Z.; YIN, L.; TANG, C.; YIN, C. Hyaluronic acid coated poly(butyl cyanoacrylate) nanoparticles as anticancer drug carriers. International Journal of Pharmaceutics, v.373, p.165-173, 2009.

JÚNIOR J.A. Avaliação do efeito do extrato etanólico das flores secas de Tithonia diversifolia (Hemsl) A. Gray veiculado em emulsão no processo de reparação tecidual induzido na pele de ratos wistar. Faculdade de Medicina do ABC. 2014.

LACERDA A.M.; et al. Screening of plants with potential phototoxic. Revista Brasileira de Farmácia. v. 92, n. 4, pp. 352-355, 2011.

NASCIMENTO G G F.; et al. Antibacterial activity of plant extracts and phytochemicals on antibiotic resistant bacteria. Brazilian Journal Microbiology. v. 31, n. 2, pp. 247-256, 2000.

NAYAK B S; PEREIRA L M P. Catharanthus roseus flower extract has wound- healing activity in Sprague Dawley rats. BMC Complementary and Alternative Medicine. V. 6, n.4, 2006.

OWOYELE V B; et al. Studies on the anti-inflammatory and analgesic properties of Tithonia diversifolia leaf extract. Journal of Ethnopharmacology. V. 90, n. 2, pp. 317-321, 2004.

RADAIC, A. Como estudar interações entre nanopartículas e sistemas biológicos. Quím. Nova, São Paulo, v. 39, n. 10, p. 1236-1244, Dec. 2016. Available from http://www.scielo.br/scielo.php?script=sci arttext\&pid $=S 0100=0422016001001236-\& \operatorname{lng}=$ en \&nrmiso $>$. Access on 25 Mar. 2017. http://dx.doi. org/10.21577/0100-4042.20160146.

REDDY L H.; MURTHY R. R. Influence od polymerization variables on the particle properties and release kinetics of methotrexate from poly(butylcyanoacrylate) nanoparticles. Acta Pharma, India,n. 54, p.103-118, 26 fev. 2004.

SCHAFFAZICK S R; et al. Caracterização e estabilidade físico-química de sistemas poliméricos nanoparticulados para administração de fármacos. Química Nova, v. 26, n.5, p. 726-737, 2003.

SANTOS J S. Nanopartículas: Aplicações cosméticas e farmacêuticas. São Paulo: Pharmabooks, 2010.

SILVA E C da et al. Análise térmica aplicada à cosmetologia. Brazilian Journal Of Pharmaceutical Sciences, São Paulo, v. 43, n. 3, p.347-356, jul. 2007.

SIMEONOVA, M. Physicochemical characterization and in vitro behavior of daunorubicin-loaded poly(butylcyanoacrylate) nanoparticles. Acta Biomaterialia, v. 5, p. 2109-2121, 2009.
SINTOV A C; SHAPIRO L. New microemulsion vehicle facilitates percutaneous penetration in vitro and cutaneous drug bioavailability in vivo. J Control Release.2004;95(2):173-183.

VAUTHIER C et al. Poly(alkylcyanoacrylates) as biodegradable materials for biomedical applications. Advanced Drug Delivery Reviews. V. 55, n. 4, p. 519548, 2003.

VOGEL A I et al. Análise Química Quantitativa. 6. ed. Rio de Janeiro: Ltc, 2017. 488 p. Disponível em: https://integrada.minhabiblioteca.com.br/ books/978-85-216-2580-3/epubcfi/6/10[ivnd.vst. idref=copyright $] ! / 4 / 10 / 6 @ 0: 0 ~>$. Acesso em: 20 out. 2017. 